\title{
CHECKING THE CZECHS: CONSENSUS AND DISSENTION AMONG CZECH ECONOMISTS
}

\author{
Dan Št'astný*
}

\begin{abstract}
:
Traditional consensus surveys among economists seem to suffer from two shortcomings. First, they target the consensus issue in a way that tends to underestimate the agreement among economists, and second, they fail to offer information about how much economists' agreed - upon position matches the actual policy, which is what, ultimately, most economists care for most.

In this paper, I introduce a redesigned survey that attempts to remedy both shortcomings at once by asking about preferred direction of policy changes in selected areas. Based on data from such survey undertaken among economists in the Czech Republic, I specifically ask about 1) the degree of consensus, and 2) the existence of a gap between such consensus and actual policy. The analysis of the survey data lends support to notions that 1) there is a solid, though not universally convincing consensus (regarding policy changes), 2) there is a gap in most areas of policy between what economists see as desirable and what the policy/makers practice.
\end{abstract}

Keywords: consensus survey, transfer of knowledge, economic policy

JEL Classification: A11, A14, Z13

\section{Introduction}

Economists often whimper about their own inconsequentiality. There indeed seems to be a large gap between economists' policy recommendations ${ }^{1}$ and the actual policy. Such divide is likely to lead to frustration and changes within the profession: changes in its motivations, agenda, methods, and conclusions. ${ }^{2}$

* Department of Economics, University of Economics, Prague; and University of New York in Prague (StastnyD@vse.cz). The author is grateful for the support of the Czech Science Foundation (GA ČR 402/09/0316). Gratitude is also extended to Peter Bolcha for administering the survey, Karel Zajíček for information technology assistance, David Lipka for valuable comments and long-time cooperation and two anonymous referees for making me make some of my hidden assumptions explicit.

1 This is not to suggest that I believe there is anything close to unanimity among all people that can be conceivably called economists on policy-related issues. I deal with this issue throughout the paper where appropriate (e.g. notes 10 and 22). At this point, suffice it to say a lack of unanimity (or any particular degree of consensus) does not preclude one from trying to identify some sort of mean opinion of the profession as a whole. Clearly, it would be absurd to claim that short of the perfect unanimity situation, there is no way we can ever decide which policy positions are in some sense closer to (or farther from) the prevailing opinion.

2 On these aspects and consequences, see Št’astný 2010 b. 
While such idea - henceforth referred to as the theory-policy gap ${ }^{3}$ - can often be found in economic literature, its evidence is mostly of an anecdotal and authoritative nature, ${ }^{4}$ and, while intuitively correct, one would perhaps appreciate a more robust substantiation of this important claim.

In order to provide it, one is naturally tempted to proceed in three steps: A) find out what economist think (recommend), B) find out what policy makers in fact do, C) compare A with B and infer the size of the gap (or, at least, its existence). As A is premised on the assertion that there is an opinion that can be meaningfully attached to the profession as a whole, it suggests that a logical starting point would be the existing surveys among economists.

In this paper, I attempt to 1) argue that the existing surveys are not very useful for analyses of consensus or the theory-policy gap; 2) introduce an alternative form of a survey that improves the first and enables the second type of the analyses, and 3 ) present and analyze the results of such survey undertaken among economists in the Czech Republic.

\section{Past Consensus Surveys}

Fueled perhaps by the notorious jibes about economists' disagreement, there are several studies looking into just what it is that economists agree and disagree upon. ${ }^{5}$ The credit for pioneering this area goes presumably to Samuel Brittan (Brittan, 1973) and to a group of authors around James Kearl (Kearl et al., 1979). ${ }^{6}$ It was the latter's work that laid foundations for many similar studies that focused on consensus among economists in particular countries. The subsequent surveys cover opinions of economists in Austria, France, Germany, and Switzerland, which are handsomely summarized by a group of gentlemen headed by Bruno Frey (Frey et al., 1984). ${ }^{7}$ A survey for the UK was understaken by Martin Ricketts and Edward Shoesmith (Ricketts and Shoesmith, 1990),

3 The inclusion of theory in the name of the idea requires some clarification. As was pointed out by an anonymous referee, economists do not have to base their policy recommendations necessarily on their knowledge of economics. While this is entirely true, the assumption that economists advise on the basis of economic theory is routinely made by economists and policy-makers alike (the latter hire the former because they are (or pretend to be) interested in professional advice, not in the personal opinion of the economist as human being. And so while all sorts of biases may and do exist among economists, since this article deals with the fate of what economists say in the hands of policy-makers, I think it appropriate to stick to this (however unrealistic factually) assumption.

4 Quotes to this effect could be found e.g. in Hayek, 1933, 121; Hutt, 1936, 34; Knight, 1951, 2-4; Jewkes, 1955, 90; von Beckerath, 1956, 16-17; or Harberger, 1993, 2.

5 Below I focus on consensus surveys directly. The degree of consensus may of course be investigated through journal articles or curricula reviews, although I hold these alternative methods inferior to surveys. This is generally because they offer greater room for interpretation than surveys (rarely does a reasonable high number of articles deal with the very same question, and rarely is this question a policy one).

6 There were some studies done prior to it, but they focused on specific policy measures or specific circumstances. See e.g. the work of J. W. Bell on the direction of the post-war US policy (Bell, 1945), which is remarkable for its shortcomings - almost naiveté - of the way the survey was executed (Frey et al., 1984).

7 Frey himself participated in the surveys for Austria, Germany, and Switzerland. 
Walter Block and Michael Walker did the same for Canada (Block and Walker, 1988) and Stephanie Geach and Duncan Reekie for South Africa (Geach and Reekie, 1991). Later, the original survey was replicated for the US: first again by the James Kearl group (Alston, Kearl, and Vaughan, 1992) and most recently by Dan Fuller and Doris Geide-Stevenson (Fuller and Geide-Stevenson, 2003). ${ }^{8}$

All these surveys attempted to analyze many different aspects of the consensus issue: the areas and the causes of that (dis)agreement (nationality, micro vs. macro, positive vs. normative etc.). In many of these tasks, the surveys and analyses were a source of valuable insights. There are, however, two problems with the design of these studies.

First, even the most agreed upon statements may still appear to some observers so disputable as to cast doubts at the intention to take them as representing the opinion of the whole profession. In fact, I try to argue below that the survey design is likely to draw a less consensual picture of the economic profession than it really is. Second, in trying to use it for the theory-policy gap analysis, one has to further compare the economists' position (indicated by the mean response to the survey statement) to political reality and judge whether (or how much) they match.

To illustrate both, take, for example, the statement on rent-control, appearing almost in all existing surveys: A ceiling on rents reduces the quantity and quality of housing available. First, even though it is, for instance, most consensual proposition in Kearl et al. 1979, it is just about $3 / 4$ of all economists who 'generally agreed', while approximately 1 in 5 felt they 'agreed with provisions' and 1 in 20 'generally disagreed' with it. Thus it may be objected that 3 out 4 is not consensual enough to proclaim it a opinion of the whole profession. Second, even if there was a perfect consensus, the statement is couched in positive terms with no explicit or direct policy implications. It may be pointed out then that if this positive statement is to be interpreted as (in fact, turned into) policy statement, one must take something - in this case, what suggests itself, the 'general economic welfare' - to be the implicit norm shared by economists. Only then can one proceed to claiming this statement to say that economists think ceilings on rent should not exist. But then again, it may be objected that this is question-begging: that economists may agree with the statement, but still be in favor of rent-control.

I try to argue below that both shortcomings of the existing surveys (with respect to the theory-policy gap investigation) can be eliminated. In the next section, I propose an alternative survey that aspires to solve both problems at once: a) it is likely to generate greater degrees of consensus, and b) the responses can readily be used to test the theory-policy gap. ${ }^{9}$

8 In a similar manner, economists paid attention to their consensus in particular fields. These include e.g. DiLorenzo and High (1988) on anti-trust policy, or Rustici (1985) on a support of minimum wage laws. Pope and Hallam (1986 and others) look into consensus among agricultural economists on agricultural issues, Whaples (1995 and 1996), respectively, on economic history among economic historians and on labor issues among labor economists, or Fuchs (1996) on health care issues. Finally, some authors focused on the consensus on economic issues among non-economists as well: e.g. Fuller, Alston and Vaughan (1995) look into politicians' opinion, while Leet and Lang (2006), map the economic educators' views.

9 Robert Whaples's recent articles are attempts at something very similar (Whaples, 2006 and 2009). 


\section{Alternative Survey}

The essence of the alternative survey lies in changing the thrust of the survey propositions in two ways: a) the propositions focus explicitly on economic policy; b) the propositions invite respondents to express opinion on the course of change the policy should take.

The first adjustment is so straightforward - given the goal of theory-policy gap investigation - as to require no further comments.

The second line of adjustment is more subtle. If one desires to identify deviations of policy (reality) from theory (prescription), there is in fact no need for knowing the absolute states of policy economists would prescribe: it is enough to know whether economists find the policy deviating from their prescriptions and if so, in which direction. Thus, instead of asking about absolute states of affairs (economic policy) economists consider desirable, the proposition will refer to direction of changes in the policy economists feel necessary and urge to be undertaken. Namely, the respondent would be invited to choose among three options regarding a given policy measure: a) the policy is too weak, i.e. it should be "tightened", practiced more vigorously etc.; b) the policy is fine, no need for changes; and c) the policy is too strong, i.e. it should be relaxed. To give an example, instead of inviting to (dis)agree with a statement that "tariffs and import quotas reduce general economic welfare", one will only indicate whether "the extent to which the trade barriers (tariffs, quotas, etc.) are used" should be a) higher, b) unchanged, or c) lower.

Rephrasing the survey propositions in such a way would likely overcome both problems one runs into when trying to use data from past consensus surveys. First, it may draw a more consensual picture of economic profession regarding the policy questions, i.e. about what should actually be done. It would not be splitting their opinions through technical considerations, contingent moreover on subjective individual understanding of premises used in propositions. Second, the normative part would already be included in the statement and there would then be no need to engage in any interpretation of positive as normative. To give an example again, economists may have their disagreements about the precise - absolute - extent to which the trade barriers should be used, but when asked about how the current extent of trade barriers should change, there is likely to be a substantial consensus that trade barriers should be lower than they are. ${ }^{10}$

Technically, one of course has to eliminate possible sources of obscurity and noise. First, the policy the propositions relate to must be specified as a single-dimensional policy measure to allow for the higher/unchanged/lower options. One can ask whether the income tax rate should be higher/unchanged/lower, but cannot ask (within one question) about the preferred changes in a tax structure. In cases where the policy cannot be reduced to one dimension (typically a structure of rates or a set of measures called regulation), it seems desirable to advise the respondents explicitly to assume that their choices in the surveys refer to all other dimensions simultaneously. For

10 This is one way to solace the skeptics regarding the possibility to derive something like a position of the economic profession as a whole (see Note 1): there may be lots of disagreements among economists, but there will be less of them when looked at from the perspective of the policy change suggested in this alternative survey. 
example, when asked about the extent of anti-trust regulation, the respondents should know the options refer to the whole package of measures and assume it is impossible to change its constituent parts. "Higher" then means that the anti-trust regulation should rather be enforced more vigorously or be made more restrictive; "lower" means the opposite; and "unchanged" means that it is either approximately what it should be or it is impossible to make it work better without changing its structure.

One may apply a similar solution to the other source of fuzziness: the current state of policy the respondents are asked to suggest adjustments to. Some policy measures may be of such local nature (e.g. rent-control, subsidies, regulation) that respondents may feel that their choice would vary across different areas. Here again, then, the respondents should assume they are taking the position with respect to all areas simultaneously. For example, when asked about the maximum rent that property owners can legally charge for an apartment, the respondents should know the options refer to all areas and assume the legal maxima cannot be changed in different areas in different directions.

Finally, it is important to point out that the data from the survey outlined above would be directly useful for studying the existence and the shape of the theory-policy gap. Apart from using the past consensus surveys to find out what economists deem to be a desirable policy and then comparing it to what the policy actually looks like, the statement in this survey relate directly to policy and economists' responses thus indicate instantly not only their (dis)agreement with policy, but also its degree and direction.

\section{Czech Economists on Economic Policy}

The survey was undertaken in December 2008 and January 2009 in cooperation with the Czech Economic Association. It was administered through a web-based system that allowed participation to invited respondents only, while at the same time keeping the identity of individual respondents anonymous to each other and to us as well throughout the process. ${ }^{11}$ A total of 708 economists were addressed (were sent the email) out of which 182 economists signed in and participated in the survey. The structure of respondents, i.e. their personal traits, can be found in Table 1.

11 There is no single person that has had access to both email list and the login data list. While I generated the login data, the representatives of the Czech Economic Association compiled and provided access to the list of addressed economists. The respective parties kept both of these lists separate at all times. When mailing out invitations, the mailing system matched each economist on the list (represented by email) with one item from the login data list.

The invited respondents (economists on the email list) came from two sources: 1) members of the Czech Economic Association (both past and present whose email addresses were available, provided by the CEA itself), and 2) economists participating in teaching economic subjects at higher education institutions (universities and colleges) in the Czech Republic (compiled chiefly by the administrator of the survey). While the former group are economists by self-identification, the latter group are economists by profession. Duplicated emails (members of both groups) were eliminated. The survey was officially administered by Peter Bolcha, a junior member of the Department of Economics, University of Economics, Prague, and the identity of the present author was kept and remained anonymous up until releasing this article. 
Table 1

Structure of Respondents (coded options and their relative frequencies

\begin{tabular}{|c|c|c|c|c|c|c|c|c|c|}
\hline \multicolumn{2}{|c|}{ Age } & \multicolumn{2}{|c|}{ Gender } & \multicolumn{2}{|c|}{$\begin{array}{c}\text { What sort of economist } \\
\text { do you consider } \\
\text { yourself to be? }\end{array}$} & \multicolumn{2}{|c|}{$\begin{array}{l}\text { Gross income per year } \\
\text { (in thousands, CZK) }\end{array}$} & \multicolumn{2}{|c|}{$\begin{array}{c}\text { Which political party's } \\
\text { program is closest to } \\
\text { your vision of economic } \\
\text { policy? }\end{array}$} \\
\hline $\begin{array}{l}25 \text { or } \\
\text { below }\end{array}$ & $\begin{array}{c}2.20 \% \\
(4)\end{array}$ & Male & $\begin{array}{c}75.82 \% \\
(138)\end{array}$ & academic & $\begin{array}{c}56.04 \% \\
(102)\end{array}$ & 250 or less & $\begin{array}{c}9.89 \% \\
(18)\end{array}$ & $\begin{array}{c}\text { ČSSD } \\
\text { (social } \\
\text { democratic) }\end{array}$ & $\begin{array}{l}12.64 \% \\
(23)\end{array}$ \\
\hline 26 to 35 & $\begin{array}{c}48.35 \% \\
(88)\end{array}$ & Female & $\begin{array}{c}22.53 \% \\
(41)\end{array}$ & private & $\begin{array}{c}20.33 \% \\
(37)\end{array}$ & 250 to 500 & $\begin{array}{l}24.18 \% \\
(44)\end{array}$ & $\begin{array}{c}\text { KDU-ČSL } \\
\text { (Christian } \\
\text { conservative) }\end{array}$ & $\begin{array}{c}3.85 \% \\
(7)\end{array}$ \\
\hline 36 to 45 & $\begin{array}{c}18.13 \% \\
(33)\end{array}$ & $\begin{array}{l}\text { declined to } \\
\text { answer }\end{array}$ & $\begin{array}{c}1.65 \% \\
(3)\end{array}$ & government & $\begin{array}{c}8.79 \% \\
(16)\end{array}$ & 500 to 750 & $\begin{array}{l}20.88 \% \\
(38)\end{array}$ & $\begin{array}{c}\text { KSČM } \\
\text { (communist) }\end{array}$ & $\begin{array}{c}2.20 \% \\
(4)\end{array}$ \\
\hline 46 to 55 & $\begin{array}{l}9.89 \% \\
(18)\end{array}$ & - & - & avocation & $\begin{array}{c}3.85 \% \\
(7)\end{array}$ & over 750 & $\begin{array}{l}26.37 \% \\
(48)\end{array}$ & $\begin{array}{c}\text { ODS } \\
\text { (civic } \\
\text { conservative) }\end{array}$ & $\begin{array}{l}43.96 \% \\
(80)\end{array}$ \\
\hline 56 to 65 & $\begin{array}{l}15.93 \% \\
(29)\end{array}$ & - & - & other & $\begin{array}{l}3.85 \% \\
(7)\end{array}$ & $\begin{array}{l}\text { declined to } \\
\text { answer }\end{array}$ & $\begin{array}{c}18.13 \% \\
(33)\end{array}$ & $\begin{array}{c}\mathrm{SZ} \\
\text { (environmental) }\end{array}$ & $\begin{array}{l}2.75 \% \\
(5)\end{array}$ \\
\hline $\begin{array}{l}66 \text { or } \\
\text { more }\end{array}$ & $\begin{array}{c}4.40 \% \\
(8)\end{array}$ & - & - & $\begin{array}{l}\text { declined to } \\
\text { answer }\end{array}$ & $\begin{array}{c}6.59 \% \\
(12)\end{array}$ & - & - & other & $\begin{array}{c}4.40 \% \\
(8)\end{array}$ \\
\hline $\begin{array}{l}\text { declined } \\
\text { to answer }\end{array}$ & $\begin{array}{l}1.10 \% \\
(2)\end{array}$ & - & - & - & - & - & - & $\begin{array}{l}\text { declined to } \\
\text { answer }\end{array}$ & $\begin{array}{l}27.47 \% \\
(50)\end{array}$ \\
\hline $\begin{array}{l}\text { blank } \\
\text { response }\end{array}$ & $\begin{array}{l}0.0 \% \\
(0)\end{array}$ & $\begin{array}{l}\text { blank } \\
\text { response }\end{array}$ & $\begin{array}{l}0.00 \% \\
(0)\end{array}$ & $\begin{array}{c}\text { blank } \\
\text { response }\end{array}$ & $\begin{array}{l}0.55 \% \\
(1)\end{array}$ & $\begin{array}{l}\text { blank } \\
\text { response }\end{array}$ & $\begin{array}{l}0.55 \% \\
(1)\end{array}$ & blank response & $\begin{array}{l}2.75 \% \\
(5)\end{array}$ \\
\hline
\end{tabular}

The survey questionnaire consisted of a total of 27 questions, out of which 22 were substantive and 5 were control questions relating to personal traits of respondents.

Of the 22 substantive propositions, one was a general opinion on the theory-policy gap, and the remaining 21 focused on changes in policy. These could be broadly classed as 3 related to international trade, 4 to fiscal policy, 2 to monetary policy, 9 to regulatory issues, and 3 to subsidies of various kinds.

Most of the issues have their counterparts in previous studies, the exception being perhaps the proposition \#21 on university education cost sharing by students, which is peculiar to Czech Republic. ${ }^{12}$

The responses to substantive propositions were coded with numerical values of 1 , 2 or 3 . The value of 1 means "higher", 2 means "unchanged" and 3 means "lower". ${ }^{13}$

12 University education is supplied free of charge to all students of public universities. Introducing some sort of students' participation in covering the cost has been a subject of public debate ever since the beginning of the transformation.

13 Proposition \#1 was an exception as only two responses were solicited: 1 means "yes" and 2 means "no". 
Table 2

Survey Propositions and Responses Overall Characteristics

\begin{tabular}{|c|c|c|c|c|c|c|c|}
\hline \multirow[b]{2}{*}{$\#$} & \multirow[b]{2}{*}{ Proposition } & \multirow[b]{2}{*}{ Mean } & \multirow[b]{2}{*}{ Std. Dev. } & \multicolumn{4}{|c|}{ Response distribution } \\
\hline & & & & $\begin{array}{c}1 \\
\text { Yes }\end{array}$ & $\begin{array}{c}2 \\
\text { No }\end{array}$ & 3 & Blank \\
\hline 1 & $\begin{array}{l}\text { Do you think the economic policy reflects } \\
\text { in a sufficient way the insights of economic } \\
\text { theory and the policy recommendation } \\
\text { made by economists (i.e. that they are not } \\
\text { systematically distorted by policy)? }\end{array}$ & 1.812 & 0.391 & $18.7 \%$ & $80.8 \%$ & - & $0.5 \%$ \\
\hline & & & & Higher & Unchanged & Lower & \\
\hline 2 & $\begin{array}{l}\text { The extent to which trade barriers (tariffs, } \\
\text { quotas etc.) are used should be: }\end{array}$ & 2.370 & 0.698 & $12.6 \%$ & $37.4 \%$ & $49.5 \%$ & $0.5 \%$ \\
\hline 3 & $\begin{array}{l}\text { The extent to which antidumping and similar } \\
\text { trade-political proceedings against foreign } \\
\text { producers are used should be: }\end{array}$ & 2.162 & 0.806 & $25.3 \%$ & $31.9 \%$ & $41.2 \%$ & $1.6 \%$ \\
\hline 4 & $\begin{array}{l}\text { The amount of attention paid by policy-makers } \\
\text { to the balance-of-trade deficit should be: }\end{array}$ & 1.867 & 0.702 & $31.9 \%$ & $48.4 \%$ & $18.7 \%$ & $1.1 \%$ \\
\hline 5 & The size of the budget deficit should be: & 2.749 & 0.558 & $6.0 \%$ & $12.6 \%$ & $79.7 \%$ & $1.6 \%$ \\
\hline 6 & $\begin{array}{l}\text { The size of the government expenditures } \\
\text { should be: }\end{array}$ & 2.584 & 0.692 & $11.5 \%$ & $17.6 \%$ & $68.7 \%$ & $2.2 \%$ \\
\hline 7 & The marginal rate of the income tax should be: & 2.421 & 0.693 & $11.5 \%$ & $33.5 \%$ & $52.7 \%$ & $2.2 \%$ \\
\hline 8 & The size of the total tax burden should be: & 2.683 & 0.582 & $6.0 \%$ & $19.2 \%$ & $73.6 \%$ & $1.1 \%$ \\
\hline 9 & $\begin{array}{l}\text { The rate of the money supply growth should } \\
\text { be: }\end{array}$ & 2.045 & 0.485 & $9.3 \%$ & $74.2 \%$ & $13.7 \%$ & $2.7 \%$ \\
\hline 10 & $\begin{array}{l}\text { The level of the inflation target set by the } \\
\text { central bank should be: }\end{array}$ & 2.039 & 0.490 & $9.9 \%$ & $74.2 \%$ & $13.7 \%$ & $2.2 \%$ \\
\hline 11 & $\begin{array}{l}\text { The extent to which environmental regulation } \\
\text { is used should be: }\end{array}$ & 1.852 & 0.805 & $39.6 \%$ & $31.9 \%$ & $25.3 \%$ & $3.3 \%$ \\
\hline 12 & $\begin{array}{l}\text { The extent to which regulation is used to } \\
\text { protect consumers should be: }\end{array}$ & 1.709 & 0.728 & $44.5 \%$ & $37.9 \%$ & $15.9 \%$ & $1.6 \%$ \\
\hline 13 & $\begin{array}{l}\text { The extent to which the anti-trust authority } \\
\text { interferes with the economy should be: }\end{array}$ & 1.944 & 0.721 & $28.6 \%$ & $47.3 \%$ & $23.1 \%$ & $1.1 \%$ \\
\hline 14 & $\begin{array}{l}\text { The difficulty with which employees can be } \\
\text { laid off should be: }\end{array}$ & 2.581 & 0.596 & $5.5 \%$ & $30.2 \%$ & $62.6 \%$ & $1.6 \%$ \\
\hline 15 & $\begin{array}{l}\text { The legislated power of the labour unions } \\
\text { should be: }\end{array}$ & 2.580 & 0.576 & $4.4 \%$ & $33.0 \%$ & $62.1 \%$ & $0.5 \%$ \\
\hline 16 & $\begin{array}{l}\text { The extent to which trade with illicit drugs is } \\
\text { regulated should be: }\end{array}$ & 1.737 & 0.800 & $47.8 \%$ & $28.6 \%$ & $22.0 \%$ & $1.6 \%$ \\
\hline 17 & $\begin{array}{l}\text { The extent to which trade with human organs } \\
\text { is regulated should be: }\end{array}$ & 1.680 & 0.714 & $45.6 \%$ & $37.9 \%$ & $14.3 \%$ & $2.2 \%$ \\
\hline 18 & $\begin{array}{l}\text { The level of legislated minimum wage should } \\
\text { be: }\end{array}$ & 2.361 & 0.721 & $14.3 \%$ & $34.6 \%$ & $50.0 \%$ & $1.1 \%$ \\
\hline 19 & $\begin{array}{l}\text { The legislated maximum rent that can be } \\
\text { charged for apartments should be: }\end{array}$ & 1.511 & 0.705 & $61.5 \%$ & $24.2 \%$ & $12.1 \%$ & $2.2 \%$ \\
\hline 20 & $\begin{array}{l}\text { The extent to which farming is subsidized by } \\
\text { government should be: }\end{array}$ & 2.440 & 0.722 & $13.7 \%$ & $28.6 \%$ & $57.7 \%$ & $0.0 \%$ \\
\hline 21 & $\begin{array}{l}\text { The extent to which university students share } \\
\text { the cost of university education should be: }\end{array}$ & 1.187 & 0.536 & $76.9 \%$ & $18.7 \%$ & $4.4 \%$ & $0.0 \%$ \\
\hline 22 & $\begin{array}{l}\text { The extent to which investment perks are used } \\
\text { should be: }\end{array}$ & 2.326 & 0.757 & $17.6 \%$ & $31.9 \%$ & $50.0 \%$ & $0.5 \%$ \\
\hline
\end{tabular}




\subsection{Consensus}

The strength of consensus on individual issues is something one may infer in various ways. ${ }^{14}$

The elementary indication of some degree of consensus can be gained by testing the null hypothesis that there is no consensus whatsoever, i.e. that there is a uniform distribution of answers. ${ }^{15}$ By using the $\mathrm{X} 2$ goodness-of-fit statistics, one can find out that the idea of no consensus can be - at $1 \%$ significance level - easily rejected in 19 out of 21 policy issues. The two exceptions were a) the extent of use of antidumping proceedings $(\# 3, \mathrm{p}$-level $=0.0169)$ and especially $\mathrm{b})$ the extent of use of environmental regulation $(\# 11, \mathrm{p}-\mathrm{level}=0.0739)$. On this account then, it seems that the proverbial idea that there is no consensus among economists is unwarranted: even on a significance level of $0.01 \%$, such a hypothesis would be rejected in 16 out of 21 cases.

Another measure of consensus, used in all surveys since Kearl et al. 1979, is the relative entropy index $(\varepsilon)$. Although such a measure is non-linear, and indicates only a rank of consensus, some authors take $\varepsilon=0.80$ as the threshold for positive indication of consensus (Fuller and Geide-Stevenson 2003, 370) ${ }^{16}$ By this standard, only 8 of the 21 propositions can be regarded as consensual. This is remarkable for two reasons that immediately come to one's mind. First, the hopes of drawing a dramatically more consensual image of economists' opinion seem to have been too optimistic. The values of the relative entropy, compared to the values in the past surveys, not only do not seem lower, but are in fact higher. The lowest relative entropy in the present survey was 0.556 (the proposition about the size of the budget deficit) while in other surveys the values of below 0.5 are not exceptional. Second, the issues that were in previous studies traditionally very consensual do not stand out in the present survey among Czech economists as the subject of much consensus. The traditional proposition on tariffs and quotas as reducing the welfare of society, for example, places always among the most consensual issues with $\varepsilon$ ranging from 0.47 to 0.81 . In the present survey (in a modified form that aspired to draw greater consensus), the tariff proposition (\#2) came out as only moderately consensual: it ranked 12 out of 21 , with $\varepsilon=0.89 .{ }^{17}$ Similarly mediocre consensus was indicated

14 These could easily include the standard deviation of response values (for standard deviations, see Table 2 above). It is not considered here, however, due to a lack of a sensible dividing line between consensus and non-consensus. One could then use such criterion for consensus ranking only.

15 Arguably, rejecting the uniform distribution is a long way from proving the existence of consensus, but it at least rules out the situations where economists as a group would not even lean to any particular opinion.

16 The relative entropy indices may not be readily comparable across different surveys. Their exact values will depend on the number of response options and the choice of whether to consider unanswered propositions as one of the options. The present study disregarded the blank answers, which is why the resulting indices are actually higher (indicating lower consensus) than in some of the previous surveys where reported indices were taking blank answers as a separate option (e.g. Kearl et al. 1979).

17 A closely related issue on the use of antidumping proceedings (\#3) fared even worse: it ranked 20 out of 21 , with $\varepsilon=0.981$. 
in the proposition regarding rent control (\#19): while in previous studies the $\varepsilon$ ranged from 0.45 to 0.80 , here it ranked 9 out of 21 with $\varepsilon=0,817$.

There are two alternative indicators of consensus. One is focused on the frequency of the modal response. If one chooses to flag propositions with the frequency of the mode at $67 \%$ or more as consensual, only 6 propositions would appear as consensual. ${ }^{18}$ The other alternative would be to focus on the least frequent of the three responses (the "anti-modal" response) to indicate consensus that policy should decidedly not change in a particular direction, i.e. a broad agreement it should stay the same or move in the other direction. ${ }^{19}$ At a frequency limit of $16.6 \%$, 15 propositions pass as consensual; at a stronger limit of $10 \%$, only 6 will pass. ${ }^{20}$

Taking all four consensus benchmarks together, the following 6 propositions pass as strongly consensual: a) the size of the budget deficit (\#5), b) the government expenditures (\#6), c) the total tax burden (\#8), d) the money supply growth (\#9), e) the level of inflation target (\#10), and f) the university education cost-sharing by students (\#21). Three out four indicators of consensus were met by the propositions relating to the employee lay-off difficulty (\#14) and the labour union power (\#15), and at least two out of four indicators were met by another 7 propositions, relating to a) trade barriers (\#5), b) the marginal income tax rate (\#7), c) consumer protection $(\# 12)$, d) organ trade regulation (\#17), e) minimum wage (\#18), f) rent control (\#19) and g) the farm subsidies (\#20). On the other hand, two propositions failed to meet any of the benchmarks: a) the use of antidumping proceedings (\#3), and b) the environmental regulation (\#11). As far as areas of policy are concerned, Czech economists showed the greatest consensus in the macroeconomic area of fiscal and monetary policy. ${ }^{21}$

18 As much as the precise choice of the limit requisite for consensus will always remain arbitrary, the choice of $67 \%$ is rationalized as double the frequency expected under uniform distribution.

19 All distributions were unimodal, the middle option of "unchanged" was never the least frequent response. This provides another rationalization of such measure of consensus: some respondents might have presumably oscillated between the two neighboring options, which is why the sum of their frequencies may be interpreted loosely as a "broad agreement".

20 The choices of threshold are again arbitrary, yet the $16.6 \%$ limit is substantiated as a half of the expected frequency under uniform distribution.

21 On the strikingly opposing nature of such consensus, see the end of Section 4.2 and Footnote 26. 
Table 3

Testing the Consensus Existence with Respect to the Survey Propositions

\begin{tabular}{|c|c|c|c|c|c|c|c|c|c|c|c|}
\hline \multirow{2}{*}{$\#$} & \multirow{2}{*}{ Propositions } & \multicolumn{2}{|c|}{$\begin{array}{l}\text { Uniform } \\
\text { distribution } \\
\text { hypothesis } \\
\left(\mathrm{X}^{2} \mathrm{GOF}\right)\end{array}$} & \multicolumn{2}{|c|}{$\begin{array}{l}\text { Relative } \\
\text { entropy } \\
\text { (RE) }\end{array}$} & \multicolumn{2}{|c|}{$\begin{array}{c}\text { Mode } \\
\text { Frequency } \\
\text { Test (MFT) }\end{array}$} & \multicolumn{2}{|c|}{$\begin{array}{l}\text { Anti-mode } \\
\text { Frequency } \\
\text { Test (AMFT) }\end{array}$} & \multicolumn{2}{|c|}{$\begin{array}{l}\text { Composite } \\
\text { consensus }\end{array}$} \\
\hline & & 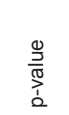 & 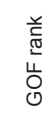 & $\omega$ & 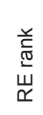 & 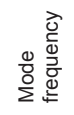 & 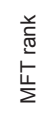 & 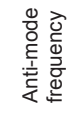 & 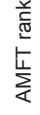 & 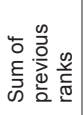 & 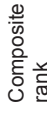 \\
\hline 2 & $\begin{array}{l}\text { The extent to which trade barriers } \\
\text { (tariffs, quotas etc.) are used should be: }\end{array}$ & 0.000 & 12 & 0.890 & 12 & 0.497 & 14 & 0.127 & 11 & 49 & 12 \\
\hline 3 & $\begin{array}{l}\text { The extent to which antidumping and } \\
\text { similar trade-political proceedings against } \\
\text { foreign producers are used should be: }\end{array}$ & 0.017 & 20 & 0.981 & 20 & 0.419 & 20 & 0.257 & 20 & 80 & 20 \\
\hline 4 & $\begin{array}{l}\text { The amount of attention paid by policy- } \\
\text { makers to the balance-of-trade deficit } \\
\text { should be: }\end{array}$ & 0.000 & 16 & 0.937 & 17 & 0.489 & 15 & 0.189 & 17 & 65 & 16 \\
\hline 5 & The size of the budget deficit should be: & 0.000 & 1 & 0.557 & 1 & 0.810 & 1 & 0.061 & 5 & 8 & 2 \\
\hline 6 & $\begin{array}{l}\text { The size of the government } \\
\text { expenditures should be: }\end{array}$ & 0.000 & 4 & 0.740 & 7 & 0.702 & 6 & 0.118 & 8 & 25 & 7 \\
\hline 7 & $\begin{array}{l}\text { The marginal rate of the income tax } \\
\text { should be: }\end{array}$ & 0.000 & 11 & 0.867 & 11 & 0.539 & 11 & 0.118 & 8 & 41 & 10 \\
\hline 8 & The size of the total tax burden should be: & 0.000 & 3 & 0.648 & 3 & 0.744 & 5 & 0.061 & 4 & 15 & 3 \\
\hline 9 & $\begin{array}{l}\text { The rate of the money supply growth } \\
\text { should be: }\end{array}$ & 0.000 & 8 & 0.651 & 4 & 0.763 & 3 & 0.096 & 6 & 21 & 4 \\
\hline 10 & $\begin{array}{l}\text { The level of the inflation target set by } \\
\text { the central bank should be: }\end{array}$ & 0.000 & 9 & 0.658 & 5 & 0.758 & 4 & 0.101 & 7 & 25 & 7 \\
\hline 11 & $\begin{array}{l}\text { The extent to which environmental } \\
\text { regulation is used should be: }\end{array}$ & 0.074 & 21 & 0.982 & 21 & 0.409 & 21 & 0.261 & 21 & 84 & 21 \\
\hline 12 & $\begin{array}{l}\text { The extent to which regulation is used } \\
\text { to protect consumers should be: }\end{array}$ & 0.000 & 17 & 0.929 & 16 & 0.453 & 19 & 0.162 & 15 & 67 & 17 \\
\hline 13 & $\begin{array}{l}\text { The extent to which the anti-trust } \\
\text { authority interferes with the economy } \\
\text { should be: }\end{array}$ & 0.000 & 19 & 0.956 & 19 & 0.478 & 17 & 0.233 & 19 & 74 & 19 \\
\hline 14 & $\begin{array}{l}\text { The difficulty with which employees } \\
\text { can be laid off should be: }\end{array}$ & 0.000 & 5 & 0.741 & 8 & 0.637 & 7 & 0.056 & 3 & 23 & 5 \\
\hline 15 & $\begin{array}{l}\text { The legislated power of the labour } \\
\text { unions should be: }\end{array}$ & 0.000 & 6 & 0.727 & 6 & 0.624 & 9 & 0.044 & 2 & 23 & 5 \\
\hline 16 & $\begin{array}{l}\text { The extent to which trade with illicit } \\
\text { drugs is regulated should be: }\end{array}$ & 0.000 & 18 & 0.950 & 18 & 0.486 & 16 & 0.223 & 18 & 70 & 18 \\
\hline 17 & $\begin{array}{l}\text { The extent to which trade with human } \\
\text { organs is regulated should be: }\end{array}$ & 0.000 & 15 & 0.914 & 14 & 0.466 & 18 & 0.146 & 14 & 61 & 15 \\
\hline 18 & $\begin{array}{l}\text { The level of legislated minimum wage } \\
\text { should be: }\end{array}$ & 0.000 & 13 & 0.903 & 13 & 0.506 & 12 & 0.144 & 13 & 51 & 13 \\
\hline 19 & $\begin{array}{l}\text { The legislated maximum rent that can } \\
\text { be charged for apartments should be: }\end{array}$ & 0.000 & 7 & 0.817 & 9 & 0.629 & 8 & 0.124 & 10 & 34 & 9 \\
\hline 20 & $\begin{array}{l}\text { The extent to which farming is } \\
\text { subsidized by government should be: }\end{array}$ & 0.000 & 10 & 0.863 & 10 & 0.577 & 10 & 0.137 & 12 & 42 & 11 \\
\hline 21 & $\begin{array}{l}\text { The extent to which university students } \\
\text { share the cost of university education } \\
\text { should be: }\end{array}$ & 0.000 & 2 & 0.594 & 2 & 0.769 & 2 & 0.044 & 1 & 7 & 1 \\
\hline 22 & $\begin{array}{l}\text { The extent to which investment perks } \\
\text { are used should be: }\end{array}$ & 0.000 & 14 & 0.925 & 15 & 0.503 & 13 & 0.177 & 16 & 58 & 14 \\
\hline
\end{tabular}




\subsection{Theory-policy gap: existence}

Overall, there is the general statement on the theory-policy relationship the respondents were asked to agree or disagree with (proposition \#1). Over $80 \%$ of respondents answered in the negative, which can be interpreted as substantial disagreement with the way economic insights are incorporated into policy. This is a fairly robust substantiation of the notion of economists' overall frustration with the transfer of knowledge.

With respect to particular areas of policy, one can detect economists' disagreement with it in several ways.

Most simply, one gets a good idea of the size of the gap (although not of its existence) by taking the deviation of the measured mean of economists' responses (assumed to be the position of the profession as a whole) ${ }^{22}$ from what it would be were economists in perfect agreement with the current policy (i.e. from the mean value of 2.0). The greater the deviation, the greater the gap.

Second, one can test the existence of the gap by testing the null hypothesis that the mean response value equals 2.0 , meaning preference for the status quo ("unchanged"). If the hypothesis is rejected, there is a reason to believe the policy does not reflect the economists' recommendation. By such standard, on 1\% significance level, 16 out of the 21 policy propositions (as judged by economists' mean opinion) seem at variance with the current policy, while 15 would have passed such a gap test even on the $0.01 \%$ significance level. The propositions that would not pass this test even on the $10 \%$ significance level relate to a) the money supply growth (\#9), b) the level of inflation target (\#10), and c) the anti-trust legislation (\#13).

An alternative test of the existence and size of the theory-policy gap is the ratio of the greater of the two pro-change response frequencies to the sum of the frequencies of the alternative responses, which I call a Strength-of-Change Index (SoCI). Its value will be 0 where there is a unanimous consensus on the appropriateness of the current policy ("unchanged"), and will rise with the size of the support for either change. The values of SoCI over 1 indicate a greater support for the particular change compared to any alternative (status quo or the change in the opposite direction), and are thus taken to be indicative of the theory-policy gap. While on such an account, 11 out of the 21 policies in consideration show a gap, 4 of these policies show a substantial degree of the gap by virtue of the SoCI exceeding the value of 2: a) the size of the budget deficit (\#5), b) the government expenditures (\#6), c) the total tax burden (\#8), and d) the university education cost-sharing by students $(\# 21) .{ }^{23}$ In contrast, the idea about a theory-policy gap is least substantiated (SoCI below 0.5) in these areas: a) the money supply growth (\#9), b) the level of inflation target (\#10), and c) the anti-trust legislation (\#13).

22 This is regardless of the actual degree of consensus as it is the signal to the outsiders - in this case, policy-makers, presumably most interested in those recommendations - on what the economic profession think should be done. If half economist were in favour of lower, and the other half in favuor of higher, tax rates, the mean response of 2.0 would indicate no theory-policy gap. After all, what else can honest policy-makers make out of such dissenting distribution of positions than think that the tax rates are just about fine.

23 The SoCI value of 2.0 indicates $2 / 3(67 \%)$ of the respondents being in favour of the particular change. As in previous cases (see note 18), 67\% threshold is double the frequency expected under uniform distribution of responses. 
Table 4

Testing the Existence of a Theory-Policy Gap with Respect to the Survey Propositions

\begin{tabular}{|c|c|c|c|c|c|c|c|c|c|}
\hline \multirow[b]{2}{*}{$\#$} & \multirow[b]{2}{*}{ Propositions } & \multicolumn{2}{|c|}{$\begin{array}{l}\text { Deviation of } \\
\text { Mean from } \\
\text { Status Quo } \\
\text { (2) }\end{array}$} & \multicolumn{2}{|c|}{$\begin{array}{l}\text { Status } \\
\text { Quo Mean } \\
\text { hypothesis }\end{array}$} & \multicolumn{2}{|c|}{$\begin{array}{l}\text { Strength of } \\
\text { Change Index } \\
\text { (SoCl) }\end{array}$} & \multicolumn{2}{|c|}{$\begin{array}{l}\text { Composite } \\
\text { Gap }\end{array}$} \\
\hline & & $\frac{\stackrel{m}{\frac{\pi}{\pi}}}{\frac{\pi}{2}}$ & 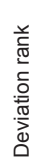 &  & 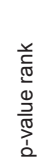 & $\frac{\stackrel{0}{\frac{\pi}{m}}}{\frac{\pi}{2}}$ &  & 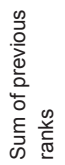 & 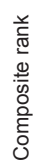 \\
\hline 2 & $\begin{array}{l}\text { The extent to which trade barriers (tariffs, quotas } \\
\text { etc.) are used should be: }\end{array}$ & 0.370 & 10 & 0.000 & 10 & 0.989 & 12 & 32 & 10 \\
\hline 3 & $\begin{array}{l}\text { The extent to which antidumping and similar } \\
\text { trade-political proceedings against foreign } \\
\text { producers are used should be: }\end{array}$ & 0.162 & 16 & 0.008 & 16 & 0.721 & 16 & 48 & 16 \\
\hline 4 & $\begin{array}{l}\text { The amount of attention paid by policy-makers to } \\
\text { the balance-of-trade deficit should be: }\end{array}$ & 0.133 & 18 & 0.012 & 17 & 0.475 & 18 & 53 & 18 \\
\hline 5 & The size of the budget deficit should be: & 0.749 & 1 & 0.000 & 2 & 4.265 & 1 & 4 & 1 \\
\hline 6 & The size of the government expenditures should be: & 0.584 & 4 & 0.000 & 6 & 2.358 & 4 & 14 & 4 \\
\hline 7 & The marginal rate of the income tax should be: & 0.421 & 9 & 0.000 & 9 & 1.171 & 9 & 27 & 9 \\
\hline 8 & The size of the total tax burden should be: & 0.683 & 3 & 0.000 & 3 & 2.913 & 3 & 9 & 3 \\
\hline 9 & The rate of the money supply growth should be: & 0.045 & 20 & 0.217 & 19 & 0.164 & 20 & 59 & 19 \\
\hline 10 & $\begin{array}{l}\text { The level of the inflation target set by the central } \\
\text { bank should be: }\end{array}$ & 0.039 & 21 & 0.286 & 20 & 0.163 & 21 & 62 & 21 \\
\hline 11 & $\begin{array}{l}\text { The extent to which environmental regulation is } \\
\text { used should be: }\end{array}$ & 0.148 & 17 & 0.016 & 18 & 0.692 & 17 & 52 & 17 \\
\hline 12 & $\begin{array}{l}\text { The extent to which regulation is used to protect } \\
\text { consumers should be: }\end{array}$ & 0.291 & 14 & 0.000 & 14 & 0.827 & 15 & 43 & 14 \\
\hline 13 & $\begin{array}{l}\text { The extent to which the anti-trust authority } \\
\text { interferes with the economy should be: }\end{array}$ & 0.056 & 19 & 0.302 & 21 & 0.406 & 19 & 59 & 19 \\
\hline 14 & $\begin{array}{l}\text { The difficulty with which employees can be laid } \\
\text { off should be: }\end{array}$ & 0.581 & 5 & 0.000 & 5 & 1.754 & 5 & 15 & 5 \\
\hline 15 & The legislated power of the labour unions should be: & 0.580 & 6 & 0.000 & 4 & 1.662 & 7 & 17 & 6 \\
\hline 16 & $\begin{array}{l}\text { The extent to which trade with illicit drugs is } \\
\text { regulated should be: }\end{array}$ & 0.263 & 15 & 0.000 & 15 & 0.946 & 13 & 43 & 14 \\
\hline 17 & $\begin{array}{l}\text { The extent to which trade with human organs is } \\
\text { regulated should be: }\end{array}$ & 0.320 & 13 & 0.000 & 12 & 0.874 & 14 & 39 & 13 \\
\hline 18 & The level of legislated minimum wage should be: & 0.361 & 11 & 0.000 & 11 & 1.022 & 10 & 32 & 10 \\
\hline 19 & $\begin{array}{l}\text { The legislated maximum rent that can be charged } \\
\text { for apartments should be: }\end{array}$ & 0.506 & 7 & 0.000 & 7 & 1.697 & 6 & 20 & 7 \\
\hline 20 & $\begin{array}{l}\text { The extent to which farming is subsidized by } \\
\text { government should be: }\end{array}$ & 0.440 & 8 & 0.000 & 8 & 1.364 & 8 & 24 & 8 \\
\hline 21 & $\begin{array}{l}\text { The extent to which university students share the } \\
\text { cost of university education should be: }\end{array}$ & 0.725 & 2 & 0.000 & 1 & 3.333 & 2 & 5 & 2 \\
\hline 22 & $\begin{array}{l}\text { The extent to which investment perks are used } \\
\text { should be: }\end{array}$ & 0.326 & 12 & 0.000 & 13 & 1.011 & 11 & 36 & 12 \\
\hline
\end{tabular}

In sum, the existence of the theory-policy gap is fairly well established both on the general level and on the level of some of the policy issues. Taking the ranks of all 3 measures of the gap together, one may design a composite gap index to rank propositions or areas of policy according to the size of the gap. 
There is a remarkable fact to be noted about the size of the gap - i.e. frustration when it comes to macroeconomic issues. While there is a widespread agreement that fiscal policy should change,$^{24}$ there is by contrast an overwhelming consensus on the appropriateness of the current monetary policy. ${ }^{25,26}$

\section{Concluding Remarks}

The ultimate rationale of this article was a contribution to the debate on the consequentiality of economic profession. Namely, I have tried to offer a better evidence of the existence of the divide between economic advice provided by economists and economic policy practiced by politicians and public officials ( $a k a$ the theory-policy gap).

The survey, designed to establish the existence of the gap, was submitted to economists in the Czech Republic, and its findings were subject of the previous section. By way of concluding, there are two important findings that merit repeating.

First, the idea that there is a greater degree of consensus regarding changes in policy (rather than regarding the absolute state of policy) was not satisfactorily established. Although almost all issues show certain opinions to which responses of economists gravitate, the degree of consensus (measured e.g. by the relative entropy index) is not higher than the consensus regarding the absolute state of policy. Failing to establish the superiority of the present type of survey in generating a consensual impression is not, of course, tantamount to denying it. It is possible that had the traditional type of survey been submitted to Czech economists, one would see lower degrees of consensus compared to the ones generated by the present type of survey. Thus, given the differences among degrees of consensus in different countries (Frey et al. 1984), it seems essential to compare the two types of surveys on the same sample of respondents. ${ }^{27}$

Second, the very existence of the gap seems established. In most of the issues the survey was looking into, the theory-policy gap is established by rejecting the null hypothesis on the "no change" option being the mean response. Moreover, in many cases the gap was very substantial, as measured by the prevalence of the "pro-change" option relative to the "no change" option.

These - and any other - conclusions may, of course, be challenged on sampling and perhaps other - grounds, which is why many observers may remain unconvinced. One will then always benefit by replicating such surveys elsewhere. Besides urging

24 All 4 propositions relating to it ( $\# 5$ through $\# 8$ ) ranked in terms of SoCI of their response distributions among the most pro-change (1st, 3rd, 4th and 9th of 21 in the composite gap index).

25 The response distributions of both propositions related to it (\#9 and \#10) were overall the least prochange of all, which implies a great deal of approval of the policy.

26 This may seem to be a result of a self-serving bias of Czech economists: there is a high share of central bank employees and fellows (past or present) among Czech economists (especially members of Czech Economic Association). On the other hand, the survey responses are far from confirming this hypothesis: all three big groups of types of economists (academic, private business and government) have similar mean responses to these statements.

27 Ideally, the Czech economists should have been submitted both types of surveys. This was not done out of concerns that length of the survey would decrease the number of respondents. 
others to multiply empirical evidence, the data of this very survey beg further analysis that can shed some light, for instance, onto the pattern ${ }^{28}$ and causes of the theory-policy gap.

\section{References}

Alston, R. M., Kearl, J. R., Vaughan, M. B. (1992), "Is There a Consensus Among Economists in the 1990s?" The American Economic Review 82, No. 2 (May): pp. 203-209.

von Beckerath, E. (1956), "The Influence of Economic Theory on Economic Policy," in Merton, R., Petersen, A. Science and the Economic Order. Frankfurt am Main: Metallgesellschaft, pp. 9-38.

Bell, J. W. (1945), "A Report on an Experiment by an Ad Hoc Consensus Committee." The American Economic Review 35, No. 2 (May): pp. 422-447.

Block, W., Walker, M. (1988), "Entropy in the Canadian Economics Profession: Sampling Consensus on the Major Issues." Canadian Public Policy/Analyse de Politiques XIV, No. 2: pp. 137-150.

Brittan, S. (1973), Is There an Economic Consensus? London: Macmillan.

DiLorenzo, T., High, J. (1988), "Antitrust and Competition Historically Considered." Economic Inquiry XXVI, No. 3: pp. 423-435.

Frey, B. S., Pommerehne, W. W., Schneider, F., Gilbert, G. (1984), "Consensus and Dissension among Economists: An Empirical Inquiry." The American Economic Review 74, No. 5 (December): pp. 986-994.

Fuchs, V. R. (1996), "Economics, Values, and Health Care Reform." The American Economic Review 86, No. 1: pp. 1-24.

Fuller, D. A., Alston, R. M., Vaughan, M. B. (1995), "The Split between Political Parties on Economic Issues: A Survey of Republicans, Democrats, and Economists." Eastern Economic Journal 21, No. 2: pp. 227-238.

Fuller, D., Geide-Stevenson, D. (2003), "Consensus among Economists: Revisited." The Journal of Economic Education: pp. 369-387.

Geach, S., Reekie, D. (1991), "Entropy in South African Economics: A Survey of Consensus and Dissent." South African Journal of Economic and Management Sciences 5, No. 2: pp. 63-86.

Harberger, A. C. (1993), "The Search for Relevance in Economics." The American Economic Review 83, No. 2: pp. 1-16.

von Hayek, F. A. (1933), "The Trend of Economic Thinking." Economica, No. 40: pp. 121-137.

Hutt, W. H. (1936), Economists and the Public, Study of Competition and Opinion. London: Jonathan Cape.

Jewkes, J. (1955), "The Economist and Change," in Economics and Public Policy. Washington, D.C.: Brookings Institution, 1954: 81-99.

Kearl, J. R., Pope, C. L., Whiting, G. C., Wimmer, L. T. (1979), "A Confusion of Economists?" The American Economic Review 69, No. 2 (May): pp. 28-37.

Knight, F. H. (1951), "The Role of Principles in Economics and Politics." The American Economic Review 41, No. 1: pp. 1-29.

Leet, D. R., Lang, N. A. (2006), "Is There a Consensus Among International Economic Educators?" Conference paper, available at http://www.csufresno.edu/cerecc/documents/leet_ASBBS_ Consensus_paper.pdf

Pope, R. D., Hallam, A. (1986), "A Confusion of Agricultural Economists? A Professional Interest Survey and Essay." American Journal of Agricultural Economics 68, No. 3 (Aug.): pp. 572-594.

28 On some aspects of the pattern of the gap as indicated by this survey, see Št'astný 2010a. 
Ricketts, M., Shoesmith, E. (1990), British Economic Opinion: A Survey of A Thousand Economists. Institute for Economic Affairs.

Rustici, T. (1985), "Public Choice View of the Minimum Wage." CATO Journal 5, No. 1: pp. 103-131.

Št’astný, D. (2010a), "Czech Economists on Economic Policy: A Survey.“ Econ Journal Watch 7, No. 3: pp. $275-287$.

Št'astný, D. (2010b). The Economics of Economics: Why Economists Aren't as Important as Garbagemen. Torino: Instituto Bruno Leoni.

Whaples, R. (1995), "Where Is There Consensus among American Economic Historians? The Results of a Survey on Forty Propositions." The Journal of Economic History 55, No. 1: pp. 139-154.

Whaples, R. (1996), "Is there Consensus among American Labor Economists? Survey Results on Forty Propositions." Journal of Labor Research 17, No 4: pp. 725-34.

Whaples, R. (2006), "Do Economists Agree on Anything? Yes!“ Economists' Voice 3, No. 9: pp. 1-6.

Whaples, R. (2009), "The Policy Views of American Economic Association Members: The Results of a New Survey." Econ Journal Watch 6, No. 3: pp. 337-348. 